\title{
The role of sustainable HRM in supply chain, profitability and resource utilization
}

\author{
Phutthiwat Waiyawuththanapoom $^{\mathrm{a}^{*}}$ and Kittisak Jermsittiparsert ${ }^{\mathrm{b}, \mathrm{c}}$
}

${ }^{a}$ College of Logistics and Supply Chain, Suan Sunandha Rajabhat University, Thailand

${ }^{b}$ Faculty of Administrative, Economic and Social Sciences, University of City Island, Cyprus

${ }^{c}$ Faculty of Social and Political Sciences, Universitas Muhammadiyah Makassar, Indonesia

\section{A B S T R A C T}

\begin{tabular}{l}
\hline Article history: \\
Received October 12, 2021 \\
Received in revised format \\
October 30,2021 \\
Accepted January 22022 \\
Available online \\
January 22022 \\
\hline Keywords: \\
Cement industry \\
Sustainable HRM \\
Operational accuracy \\
Supply chain, profitability \\
Resource utilization
\end{tabular}

\section{Introduction}

In the current competitive environment, the competition among the various industries is increasing which requires higher performance from the companies to survive in the market. As with the increase in the companies, the competition is also increasing. The competition is also increasing in the cement industry. Number of companies in the cement industry are increasing day by day and in the same direction the competition in this industry is also increasing with great speed. However, the increasing competition in this industry requires better performance of the companies which is not easy to achieve. As there is a significant relationship between competition and performance (Deng, Zhang, Ahmad, \& Draz, 2019; Pöchmüller, Schwingshackl, Colombani, \& Hoffmann, 2016) which shows that to achieve the better performance, the survival in the competitive environment is quite important and it is one of the challenges for businesses.

Along with the other countries, the Indonesian cement industry also plays an important role through different aspects. This industry in Indonesia has several benefits to Indonesia. For instance, the cement industry has important participation to increase economic growth. As this industry generates heavy return which has a contribution to increase the overall nation's income. Increase in the revenue of the Indonesian cement industry also increases the economic contribution. Furthermore, it also has contributions at the local level in Indonesia. At the local level, the cement manufacturing companies are contributing to the welfare of the people by providing job opportunities. Hence, in this direction, the cement industry contribution to create employment opportunities cannot be neglected. Increasing contribution of cement industry in the economy as well as at local level required better performance of this industry. Higher performance of Indonesian cement industry is required to contribute to all sectors such as local and national level. The contribution of this industry can also be increased at international level by exporting cement to other countries. Hence, the cement industry has vital importance among various countries (Omrani,

* Corresponding author

E-mail address: phutthiwat.wa@ssru.ac.th (P. Waiyawuththanapoom)

(C) 2022 Growing Science Ltd. All rights reserved.

doi: $10.5267 /$ j.uscm.2022.1.002 
Jafari, \& Mansori, 2019; Shubbar et al., 2019). However, the Indonesian cement industry is facing several issues in relation to the performance as well as other related industries having negative influence on the industry. Number of issues in the cement companies has a negative influence on overall performance. For instance, this industry is facing issues related to the supply chain. As the supply chain is the most important part of various companies (Ahmed et al., 2020), therefore, the low level of supply chain among the companies has negative influence. Moreover, these companies are facing low profitability. Low profitability is also one of the issues in this industry. The profitability is the major objective of the companies (Darina, Azam, \& Bayu, 2020), therefore, it should be increased through different strategies. Finally, resource utilization is an issue in these companies. Resource utilization is a major part of cement manufacturing companies. However, misuse of resources shows a negative effect on the companies and decreases the overall performance. Hence, the issues related to the supply chain, profitability and resource utilization must be resolved.

According to the current study, sustainable human resource management (HRM) has the ability to increase the performance by decreasing these issues. Better implementation of sustainable HRM has positive influence to increase the performance through operational accuracy. HRM practices has major importance to train the employees to do operations in a better way (Kerdpitak \& Jermsittiparsert, 2020). Accuracy in the operation has the potential to increase the supply chain, profitability and resource utilization. Cement companies should have a competent HRM team to select the competent people for jobs in the related field. Hiring of incompetent employees in the organization may lead to decrease the performance by decreasing the operational accuracy. Therefore, the current study is one of the attempts to highlight the role of sustainable HRM and operational accuracy in supply chain, profitability and resource utilization. Sustainable HRM is important because several studies examined the idea in several companies and found valuable results (Giannakis, Chalikias, \& Tsirigoti, 2019; Guerci, Decramer, Van Waeyenberg, \& Aust, 2019). Hence, Indonesian cement manufacturing companies should promote supply chain, profitability and resource utilization with the help of sustainable HRM and operational accuracy. Hence, the objective of this study is to examine the role of sustainable HRM in supply chain, profitability and resource utilization. The relationship between sustainable HRM, operational accuracy, supply chain, profitability and resource utilization were examined. Number of studies examined the cement industry in the literature (Clavier, Watts, Liu, Ferraro, \& Townsend, 2019; Gonçalves, Silva, de Brito, Fernández, \& Esquinas, 2020), however, literature have not examined the effect of sustainable HRM and operational accuracy on supply chain, profitability and resource utilization in the cement industry of Indonesia.

\section{Literature Review}

Cement industry is one of the most important industries globally. As this industry has the most important role in the construction industry. Construction work in the whole world is majorly based on the cement industry. As the construction work is increasing in the countries, in the same direction, it also required heavy production of cement to fulfil the growing requirement of cement. Work in the construction industry is not possible without the participation of the cement industry. Therefore, construction companies are also dependent on cement companies. The construction companies of Indonesia are also majorly based on the cement industry. However, to fulfil the growing importance of the cement industry in Indonesia, it requires higher performance of this industry. As previous studies show that higher performance of cement industry is required to fulfil all the requirements (Omrani et al., 2019; Saleh, El-Sheikh, Elshereafy, \& Essa, 2019; Sarc, Seidler, Kandlbauer, Lorber, \& Pomberger, 2019; Shubbar et al., 2019). Performance of this industry can be increased with the help of different ways. The performance can be increased with the help of sustainable HRM practices. Better practices of sustainable HRM can increase the performance through operational accuracy. According to this study, better performance requires a better supply chain system. High profitability and proper resources utilization. Lacking in any area can decrease the performance. For instance, the lack of a supply chain can decrease the overall performance. Lacking in profitability will lead to the failure of major objectives of the cement companies and lacking in resources utilization has the potential to decrease the performance of this industry.

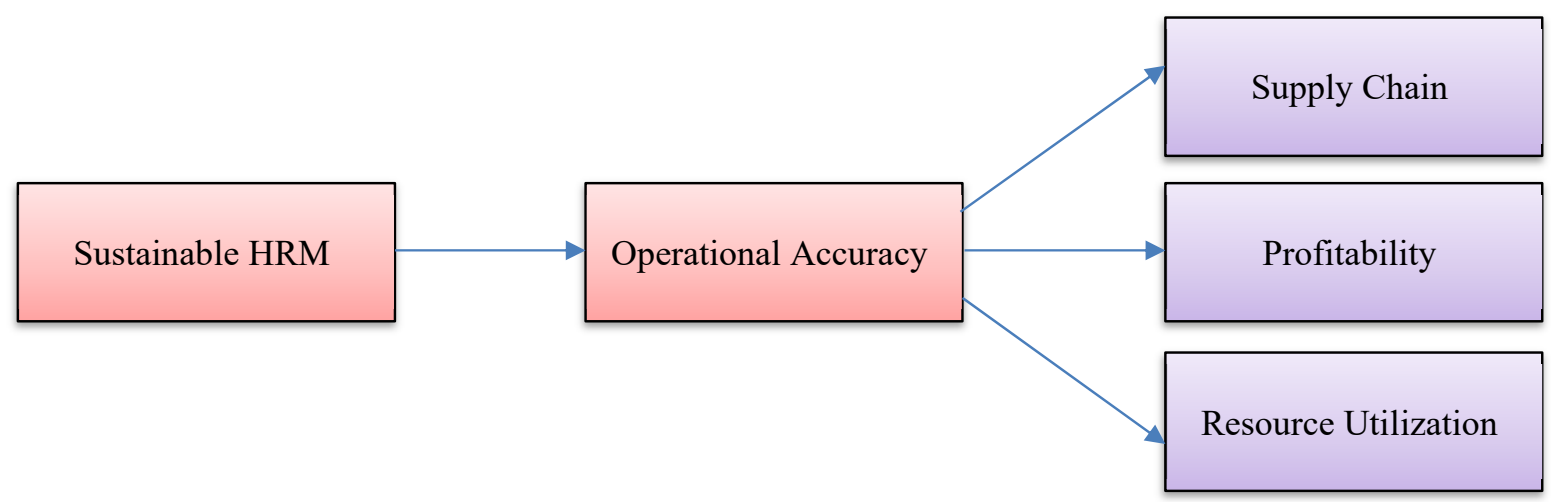

Fig. 1. Theoretical framework of the study showing the relationship between sustainable HRM, operational accuracy, supply chain, profitability and resource utilization 
Therefore, it is really important for the cement industry to enhance overall performance. Therefore, this study is an attempt to show the role of sustainable HRM in supply chain, profitability and resource utilization. Fig. 1 shows the relationship between sustainable HRM, operational accuracy, supply chain, profitability and resource utilization. Human resource is the vital part of any industry. In each company, HRM has a separate department which has several duties to perform. The major role of the human resource department is to handle the employees of the company. It has the responsibility to recruit talented employees for the welfare of the company and to fulfill the needs of the company. The transfer of the employees from one department to another department is also the duty of the human resource team. Moreover, the training activities for the employees are also handled by the HR department. Therefore, it is central to the operations of the company. Better training of the employees shows a positive effect on their working which has a positive role to enhance the performance. Therefore, training has vital importance in operational accuracy (Ahmad et al., 2019; Maina \& Bula, 2019).

\section{Hypothesis 1. Sustainable HR has a relationship with operational accuracy.}

Furthermore, operational accuracy has a relationship with the supply chain. Sustainable HR effect on operational accuracy and operational accuracy has an effect on supply chain. In the cement industry, the supply chain plays a critical role. In cement manufacturing companies, the supply of raw material has vital importance. The timely manufacturing of cement is based on the timely delivery of raw material to the companies. Furthermore, the supply chain is also vital to deliver cement to the customers which is important because it has an effect on the satisfaction level of employees. Previous studies show that the supply chain has a relationship with the cement industry (Khaksar, Abbasnejad, Esmaeili, \& Tamošaitiené, 2016; Sharma \& Khanna, 2020). Increase in the supply chain among the cement making companies increases the performance of these companies which is important and the major objective of all the companies. Therefore, the operational performance in cement companies has a vital role in the supply chain. The smooth working of operations in the cement companies is the guarantee of supply chain smooth working which leads to the following hypothesis.

Hypothesis 2. Operational accuracy has a relationship with the supply chain.

Moreover, according to the current study, operational accuracy also has a relationship with profitability. Profitability is the most vital area of any organization including cement manufacturing companies. As profitability is the very first objective of companies which leads to success in the market. Low profit generating companies cannot survive in the market since heavy investment in the market always requires considerable profit to pay back the invested amount and to increase the level of success by maintaining the business activities. However, the low profit level among the cement companies cannot compete in the market. As various previous studies show the important relationship of profitability with performance among the various companies (Murty \& Chowdary, 2018; Snapp et al., 2018). In this direction, operational accuracy has a vital influence on profitability. Increase in the operational accuracy has a significant relationship with profitability.

Hypothesis 3. Operational accuracy has a relationship with profitability.

Finally, operational accuracy also has a relationship with resource utilization. Resources utilization is the major area of any organization. To get higher performance, proper utilization of resources is most important. Because the sources are the key part of any organization for the performance (Altaf, Hameed, Nadeem, \& Arfan, 2019), however, improper utilization of resources has a negative effect on the performance. Misutilization of resources is also common among the companies which shows a negative effect on performance. Therefore, companies should avoid misutilization of resources (Rajan et al., 2019). In proper utilization of resources, operational accuracy is most important. Therefore, increase in operation accuracy increases the proper utilization of resources. Nevertheless, this study also examining the mediating role of operational accuracy which is highlighted in following hypotheses:

Hypothesis 4. Operational accuracy has a relationship with resource utilization.

Hypothesis 5. Operational accuracy mediates the relationship between sustainable HRM and supply chain.

Hypothesis 6. Operational accuracy mediates the relationship between sustainable HRM and profitability.

Hypothesis 7. Operational accuracy mediates the relationship between sustainable HRM and resources utilization.

\section{Research Methodology}

The relationship between sustainable HRM, operational accuracy, supply chain, profitability and resource utilization were examined after designing the questionnaire. For the design of the questionnaire, five variables; sustainable HRM, operational accuracy, supply chain, profitability and resource utilization were measured. The measures for these variables were adapted from the previous studies. Questionnaire was designed for data collection in which personal information of the respondents were also noted such as age, income, education and marital status to get findings related to the demographics of the respondents. The second section of the study was based on the scale items related to the sustainable HRM, operational accuracy, supply chain, profitability and resource utilization. Hence, a survey was applied in this study for data collection (Hameed \& Naveed, 2019). For this study, the cement industry of Indonesia was selected. Cement industry was selected because this industry was facing several issues related to the supply chain, profitability and resource utilization. Therefore, 
this study is an attempt to examine the solution for these issues. Therefore, data was collected from the cement manufacturing companies of Indonesia. Employees of these companies were the respondents of the study. Finally, 450 questionnaires were distributed among the cement manufacturing companies. From total questionnaires, 230 was used for data analysis. Simple random sampling was applied for data collection (Siuly, Li, \& Wen, 2011). Before applying simple random sampling, the cluster sampling was applied to make clusters (Ul-Hameed, Mohammad, Shahar, Aljumah, \& Azizan, 2019). Additionally, after data collection, the current study examined the missing value in the data (Aydin \& ŞENOĞLU, 2018). As the missing value has a tendency to affect the original results of the study. Missing values as well as outliers are given in Table 1. Other errors such as normality can also affect the results. However, the current study used Partial Least Square (PLS) which is quite suitable to analyze data both in normal and non-normal causes (F. Hair Jr, Sarstedt, Hopkins, \& G. Kuppelwieser, 2014; Hair, 2010; Hair Jr, Hult, Ringle, \& Sarstedt, 2016).

Table 1

Data Statistics

\begin{tabular}{|c|c|c|c|c|c|c|c|c|c|}
\hline & No. & Missing & Mean & Median & Min & Max & SD & Kurtosis & Skewness \\
\hline SHRM1 & 1 & 0 & 3.643 & 4 & 1 & 5 & 0.998 & -1.25 & -0.614 \\
\hline SHRM2 & 2 & 0 & 2.988 & 4 & 1 & 5 & 1.16 & -0.663 & -1.387 \\
\hline SHRM3 & 3 & 0 & 3.476 & 4 & 1 & 5 & 1.21 & -0.519 & -0.636 \\
\hline SHRM4 & 4 & 0 & 3.458 & 4 & 1 & 5 & 1.262 & -0.698 & -0.523 \\
\hline SHRM5 & 5 & 0 & 3.375 & 4 & 1 & 5 & 0.943 & -1.869 & -0.444 \\
\hline SHRM6 & 6 & 0 & 2.952 & 4 & 1 & 5 & 1.285 & -0.823 & -0.521 \\
\hline SHRM7 & 7 & 0 & 3.506 & 4 & 1 & 5 & 1.185 & -0.61 & -0.458 \\
\hline SHRM8 & 8 & 0 & 3.577 & 4 & 1 & 5 & 1.162 & -0.344 & -1.637 \\
\hline OA1 & 9 & 0 & 3.696 & 4 & 1 & 5 & 0.967 & -1.492 & -0.777 \\
\hline OA2 & 10 & 0 & 3.571 & 4 & 1 & 5 & 1.27 & -0.776 & -0.557 \\
\hline OA3 & 11 & 0 & 2.953 & 4 & 1 & 6 & 1.336 & -0.972 & -0.419 \\
\hline OA4 & 12 & 0 & 3.542 & 4 & 1 & 5 & 1.174 & -0.478 & -1.624 \\
\hline OA5 & 13 & 0 & 3.571 & 4 & 1 & 5 & 1.183 & -1.729 & -0.488 \\
\hline SUC1 & 14 & 0 & 3.524 & 4 & 1 & 6 & 0.915 & -0.599 & -0.388 \\
\hline SUC2 & 15 & 0 & 3.661 & 4 & 1 & 5 & 1.028 & -0.638 & -0.307 \\
\hline SUC3 & 16 & 0 & 2.985 & 4 & 1 & 5 & 1.053 & -0.752 & -0.295 \\
\hline SUC4 & 17 & 0 & 3.458 & 4 & 1 & 5 & 1.169 & -1.395 & -0.62 \\
\hline PRO1 & 18 & 0 & 3.494 & 4 & 1 & 5 & 0.968 & -0.718 & -0.535 \\
\hline PRO2 & 19 & 0 & 3.411 & 4 & 1 & 5 & 1.265 & -0.899 & -1.439 \\
\hline PRO3 & 20 & 0 & 3.565 & 4 & 1 & 5 & 1.208 & -0.631 & -0.523 \\
\hline PRO4 & 21 & 0 & 3.595 & 4 & 1 & 5 & 1.181 & -1.433 & -0.591 \\
\hline RU1 & 22 & 0 & 2.996 & 4 & 1 & 5 & 1.267 & -0.492 & -1.777 \\
\hline RU2 & 23 & 0 & 3.583 & 4 & 1 & 5 & 1.288 & -0.777 & -0.582 \\
\hline RU3 & 24 & 0 & 3.506 & 4 & 1 & 6 & 1.309 & -0.89 & -0.439 \\
\hline RU4 & 25 & 0 & 3.625 & 4 & 1 & 5 & 1.199 & -0.443 & -0.686 \\
\hline RU5 & 26 & 0 & 3.958 & 4 & 1 & 5 & 0.96 & 1.498 & -1.139 \\
\hline RU6 & 27 & 0 & 3.958 & 4 & 1 & 5 & 1.014 & 0.565 & -0.953 \\
\hline
\end{tabular}

Note: SHRM = Sustainable HRM; OA = Operational Accuracy; SUC = Supply Chain; PRO = Profitability; RU = Resource Utilization

\section{Findings}

Utilization of PLS for data analysis is most effective to get results from primary data (Hair, 2010; Hair, Sarstedt, Pieper, \& Ringle, 2012; Henseler et al., 2014). It is given in Fig. 2 that sustainable HRM is measured by using eight scale items. Operational accuracy is measured through five scale items, supply chain is measured through four scale items, profitability is measured through four scale items and finally, resource utilization is measured through four scale items. Two items were excluded from the survey due to low factor loadings. In the current study, as shown in Table 2, all the scale items for all the variables; sustainable HRM, operational accuracy, supply chain, profitability and resource utilization have factor loadings above minimum threshold of 0.5 .

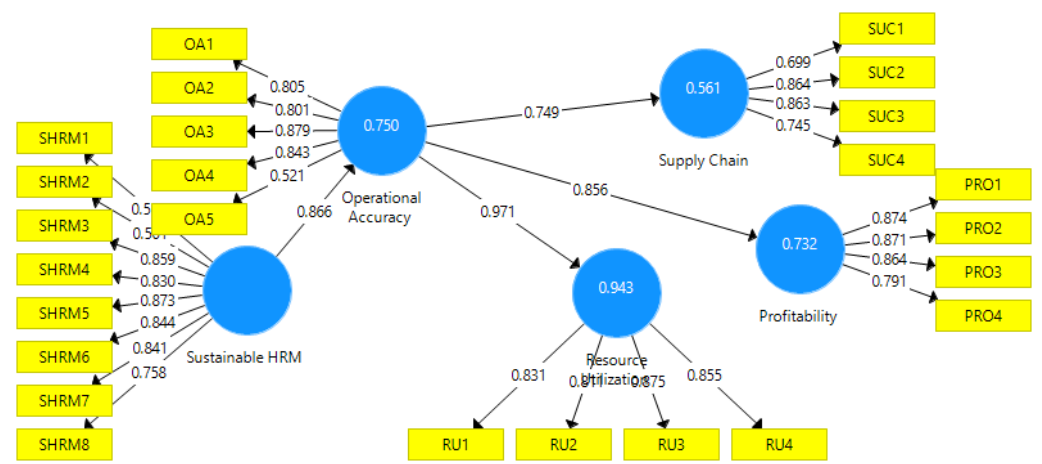

Fig. 2. Measurement Model 
Table 2

Factor Loadings

\begin{tabular}{|c|c|c|c|c|c|}
\hline & Operational Accuracy & Profitability & Resource Utilization & Supply Chain & Sustainable HRM \\
\hline OA1 & 0.805 & & & & \\
\hline OA2 & 0.801 & & & & \\
\hline OA3 & 0.879 & & & & \\
\hline OA4 & 0.843 & & & & \\
\hline OA5 & 0.521 & & & & \\
\hline PRO1 & & 0.874 & & & \\
\hline $\mathrm{PRO} 2$ & & 0.871 & & & \\
\hline PRO3 & & 0.864 & & & \\
\hline PRO4 & & 0.791 & & & \\
\hline RU1 & & & 0.831 & & \\
\hline RU2 & & & 0.811 & & \\
\hline RU3 & & & 0.875 & & \\
\hline RU4 & & & 0.855 & & \\
\hline SHRM1 & & & & 0.519 & \\
\hline SHRM2 & & & & 0.501 & \\
\hline SHRM3 & & & & 0.859 & \\
\hline SHRM4 & & & & 0.83 & \\
\hline SHRM5 & & & & 0.873 & \\
\hline SHRM6 & & & & 0.844 & \\
\hline SHRM7 & & & & 0.841 & \\
\hline SHRM8 & & & & 0.758 & \\
\hline SUC1 & & & & & 0.699 \\
\hline SUC2 & & & & & 0.864 \\
\hline SUC3 & & & & & 0.863 \\
\hline SUC4 & & & & & 0.745 \\
\hline
\end{tabular}

Note: SHRM = Sustainable HRM; OA = Operational Accuracy; SUC = Supply Chain; PRO = Profitability; RU = Resource Utilization

It is given in Table 3 that; sustainable HRM, operational accuracy, supply chain, profitability and resource utilization have composite reliability (CR) above 0.7 . Moreover, it is found that average variance extracted (AVE) is above 0.5 for sustainable HRM, operational accuracy, supply chain, profitability and resource utilization. Hence, both CR and AVE achieved the minimum level. Finally, the last step of PLS-SEM is discriminant validity, given in Table 4 and achieved with the help of cross-loadings (Fornell \& Larcker, 1981).

Table 3

Reliability and Convergent Validity

\begin{tabular}{lllll}
\hline & Alpha & rho_A & CR & AVE \\
\hline Operational Accuracy & 0.83 & 0.853 & 0.883 & 0.913 \\
Profitability & 0.872 & 0.874 & 0.609 & 0.724 \\
Resource Utilization & 0.864 & 0.866 & 0.873 & 0.711 \\
Supply Chain & 0.81 & 0.834 & 0.633 & 0.917 \\
Sustainable HRM & 0.894 & 0.917 & 0.588 \\
\hline
\end{tabular}

Note: SHRM = Sustainable HRM; OA = Operational Accuracy; SUC = Supply Chain; PRO = Profitability; RU = Resource Utilization

\section{Table 4}

Cross-Loadings

\begin{tabular}{|c|c|c|c|c|c|}
\hline & Operational Accuracy & Profitability & Resource Utilization & Supply Chain & Sustainable HRM \\
\hline OA1 & 0.805 & 0.654 & 0.821 & 0.551 & 0.64 \\
\hline $\mathrm{OA} 2$ & 0.851 & 0.716 & 0.814 & 0.515 & 0.684 \\
\hline $\mathrm{OA} 3$ & 0.879 & 0.746 & 0.865 & 0.643 & 0.757 \\
\hline OA4 & 0.843 & 0.736 & 0.826 & 0.565 & 0.767 \\
\hline OA5 & 0.721 & 0.44 & 0.374 & 0.703 & 0.493 \\
\hline PRO1 & 0.708 & 0.874 & 0.729 & 0.615 & 0.805 \\
\hline $\mathrm{PRO} 2$ & 0.763 & 0.871 & 0.766 & 0.662 & 0.857 \\
\hline PRO3 & 0.742 & 0.864 & 0.737 & 0.691 & 0.826 \\
\hline PRO4 & 0.696 & 0.791 & 0.704 & 0.577 & 0.706 \\
\hline RU1 & 0.799 & 0.657 & 0.831 & 0.551 & 0.65 \\
\hline RU2 & 0.776 & 0.721 & 0.811 & 0.526 & 0.681 \\
\hline RU3 & 0.864 & 0.771 & 0.875 & 0.651 & 0.749 \\
\hline RU4 & 0.835 & 0.761 & 0.855 & 0.57 & 0.767 \\
\hline SHRM1 & 0.429 & 0.362 & 0.361 & 0.557 & 0.519 \\
\hline SHRM2 & 0.387 & 0.328 & 0.281 & 0.548 & 0.501 \\
\hline SHRM3 & 0.75 & 0.77 & 0.75 & 0.873 & 0.859 \\
\hline SHRM4 & 0.715 & 0.853 & 0.718 & 0.89 & 0.83 \\
\hline SHRM5 & 0.751 & 0.857 & 0.754 & 0.895 & 0.873 \\
\hline SHRM6 & 0.729 & 0.778 & 0.732 & 0.899 & 0.844 \\
\hline SHRM7 & 0.72 & 0.827 & 0.702 & 0.872 & 0.841 \\
\hline SHRM8 & 0.706 & 0.78 & 0.696 & 0.874 & 0.758 \\
\hline SUC1 & 0.457 & 0.401 & 0.37 & 0.699 & 0.842 \\
\hline SUC2 & 0.524 & 0.511 & 0.437 & 0.864 & 0.895 \\
\hline SUC3 & 0.495 & 0.509 & 0.427 & 0.863 & 0.88 \\
\hline SUC4 & 0.776 & 0.81 & 0.778 & 0.745 & 0.826 \\
\hline
\end{tabular}

Note: SHRM = Sustainable HRM; OA = Operational Accuracy; SUC = Supply Chain; PRO = Profitability; RU = Resource Utilization 
Further to this study, after the factor loadings, the structural model of PLS was preferred to examine the effect of sustainable HRM on operational accuracy, the effect of operational accuracy was examined on the supply chain. Moreover, the effect of operational accuracy was examined on profitability and finally, the effect of operational accuracy was examined in resource utilization. These relationships were examined with the help of PLS-SEM (Addison et al., 2020; W. U. Hameed, Basheer, Iqbal, Anwar, \& Ahmad, 2018; Henseler \& Chin, 2010; Henseler \& Fassott, 2010; Henseler, Ringle, \& Sinkovics, 2009) as shown in Fig. 3. Finally, the results in Table 5 shows that sustainable HRM has a positive effect on operational accuracy. Better sustainable HRM has a positive role in operational accuracy. Moreover, it is found that operational accuracy has a positive effect on the supply chain. Operational accuracy has a positive effect on profitability. Finally, operational accuracy has a positive effect on resource utilization. Hence, operational accuracy has a significant positive effect on supply chain, profitability and resource utilization.

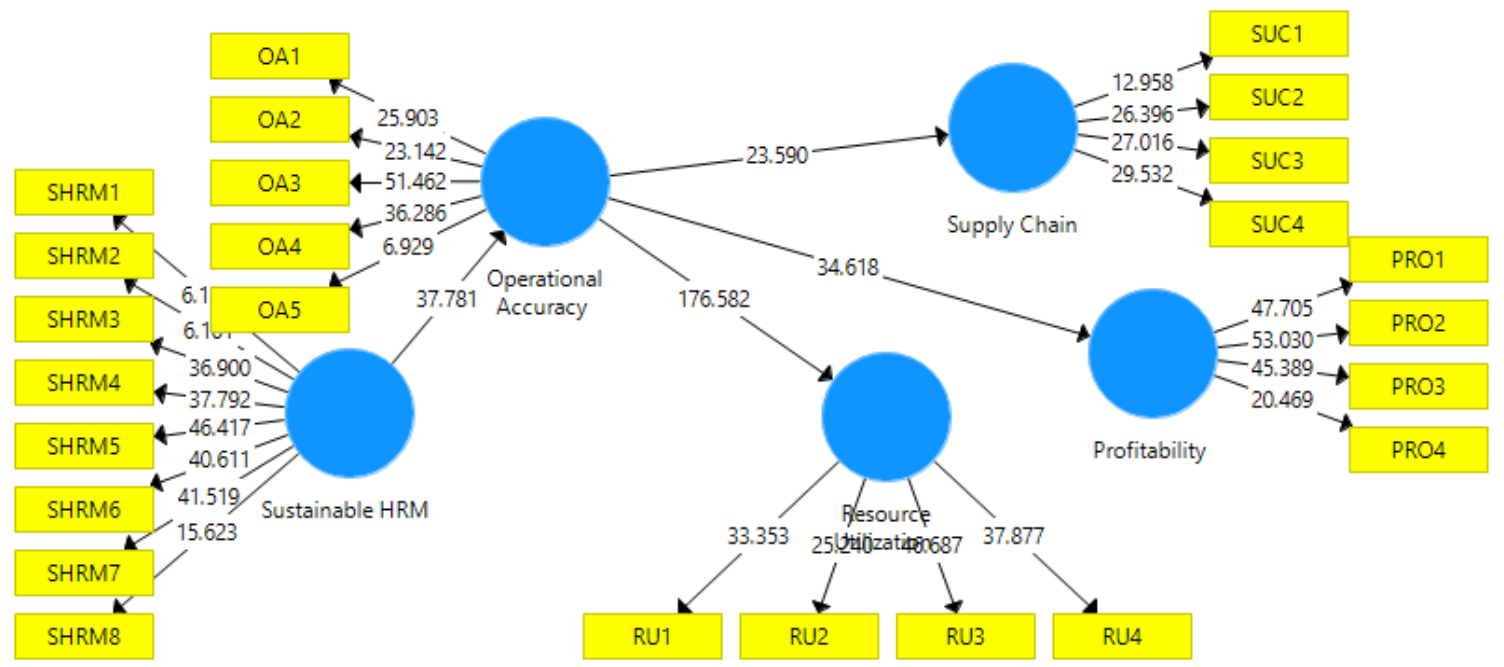

Fig. 3. Structural Model

Table 5

Direct Effect Results

\begin{tabular}{|c|c|c|c|c|c|}
\hline & (O) & (M) & SD & T Statistics & P Values \\
\hline Operational Accuracy $\rightarrow$ Profitability & 0.856 & 0.857 & 0.025 & 34.618 & 0 \\
\hline Operational Accuracy $\rightarrow$ Resource Utilization & 0.971 & 0.971 & 0.006 & 176.582 & 0 \\
\hline Operational Accuracy $\rightarrow$ Supply Chain & 0.749 & 0.751 & 0.032 & 23.59 & 0 \\
\hline Sustainable HRM $\rightarrow$ Operational Accuracy & 0.866 & 0.868 & 0.023 & 37.781 & 0 \\
\hline
\end{tabular}

Note: SHRM = Sustainable HRM; OA = Operational Accuracy; SUC = Supply Chain; PRO = Profitability; RU = Resource Utilization

The mediating role of operational accuracy was examined between sustainable HRM and supply chain. The mediating role of operational accuracy was examined between sustainable HRM and profitability. Finally, the mediating role of operational accuracy was examined between sustainable HRM and resource utilization. The mediation effect results are given in Table 6. The mediating role of operational accuracy between sustainable HRM and supply chain is significant and positive with tvalue 16.065. The mediating role of operational accuracy between sustainable HRM and profitability is significant and positive with t-value 18.877. The mediating role of operational accuracy between sustainable HRM and resource utilization is significant and positive with t-value 35.339. Thus, operational accuracy as mediating variables reflects the positive effect of sustainable HRM on supply chain, profitability and resource utilization. The mediation effect of operation accuracy was examined by following the instructions of Preacher and Hayes (2008). Moreover, all the mediation effect histogram is given in Figure 4, 5 and 6. Finally, this study also examined the r-square value which is 0.561 for the supply chain which is moderate. The r-square for profitability is 0.732 which is strong (Chin, 1998). Finally, the-r-square value for resources utilization is 0.943 which is also strong.

\section{Table 6}

Indirect Effect Results

\begin{tabular}{|c|c|c|c|c|c|}
\hline & (O) & (M) & SD & T Statistics & P Values \\
\hline Sustainable HRM $\rightarrow$ Operational Accuracy -> Profitability & 0.741 & 0.744 & 0.039 & 18.877 & 0 \\
\hline Sustainable HRM $\rightarrow$ Operational Accuracy $->$ Resource Utilization & 0.841 & 0.843 & 0.024 & 35.339 & 0 \\
\hline Sustainable HRM $\rightarrow$ Operational Accuracy $->$ Supply Chain & 0.648 & 0.652 & 0.04 & 16.065 & 0 \\
\hline
\end{tabular}

Note: SHRM = Sustainable HRM; OA = Operational Accuracy; SUC = Supply Chain; PRO = Profitability; RU = Resource Utilization 


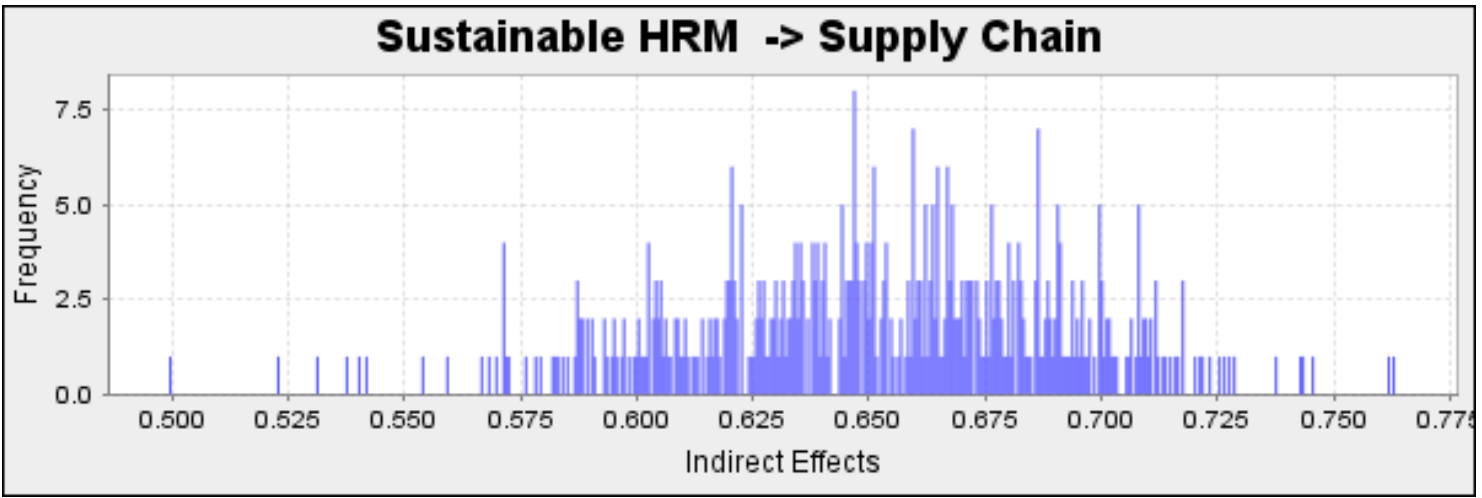

Fig. 4. Indirect Effect Histogram: Sustainable HRM $\rightarrow$ Operational Accuracy $->$ Supply Chain

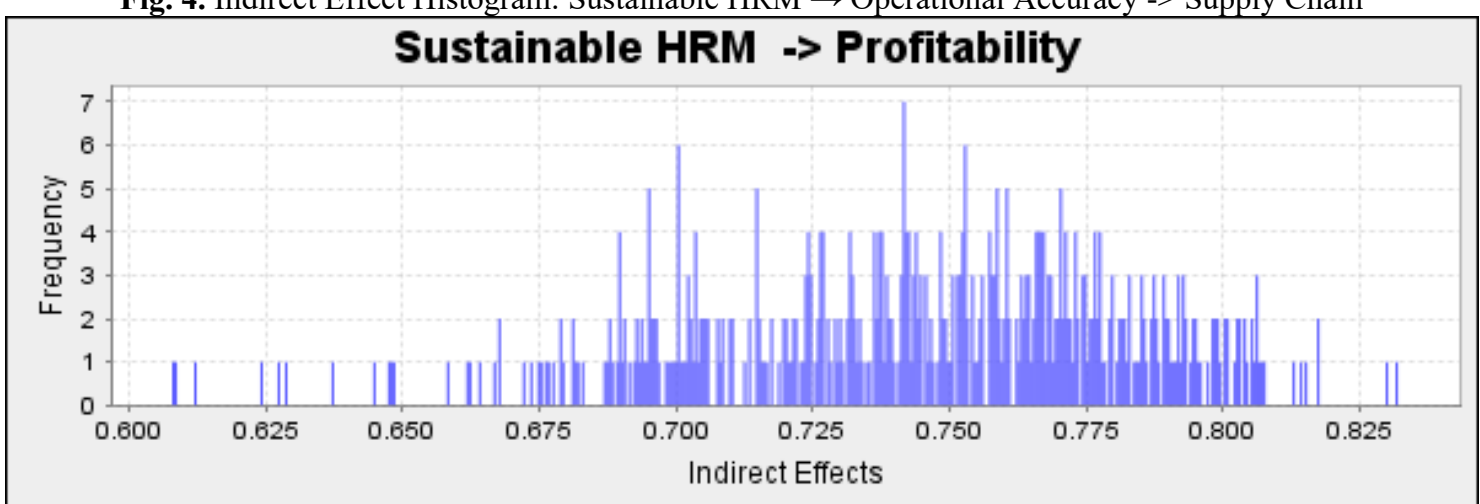

Fig. 5. Indirect Effect Histogram: Sustainable HRM $\rightarrow$ Operational Accuracy $->$ Profitability

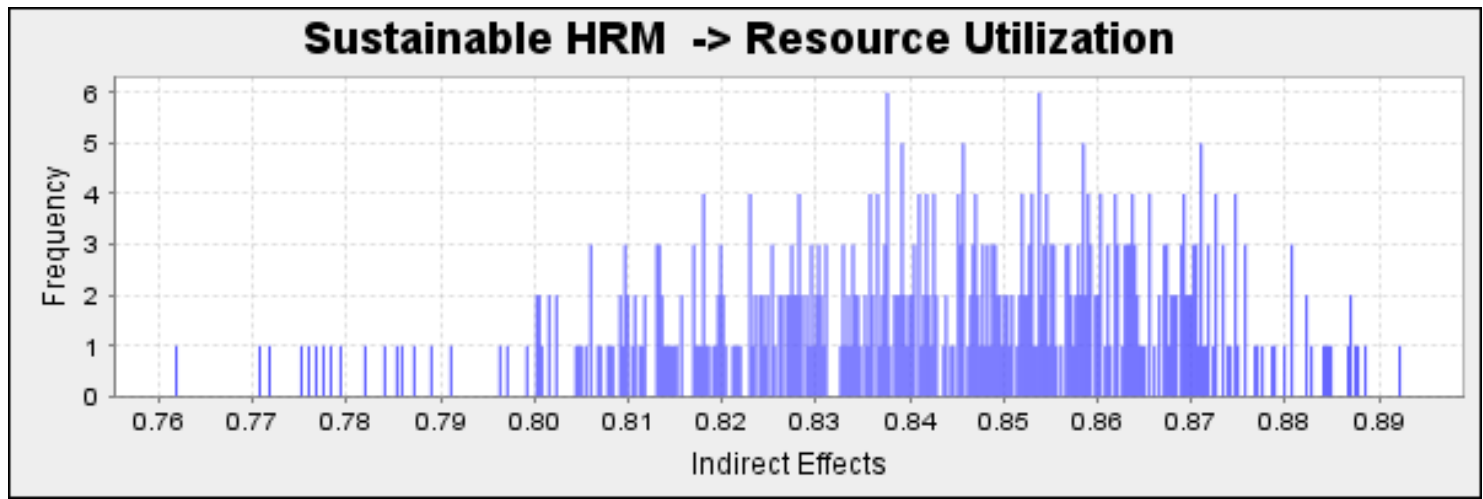

Fig. 6. Indirect Effect Histogram: Sustainable HRM $\rightarrow$ Operational Accuracy $\rightarrow$ Resource Utilization

\section{Conclusion}

The current study is the vital study in the field of cement industry and examined the relationship between sustainable HRM, operational accuracy, supply chain, profitability and resource utilization. Objective of this study was to examine the role of sustainable HRM in supply chain, profitability and resource utilization. Data were collected from the Indonesian companies and employees of these companies was the respondents of the study. Outcomes of the study provided vital outcomes and found the major role of supply chain activities in the field of cement industry. Better supply chain activities among the cement companies play major contribution to support cement industry. Moreover, it is found that profitability is key of success in cement industry. Along with this, resource utilization has major participation to increase the performance of this industry. However, all these elements; supply chain, profitability and resources accuracy can be increased with the help of sustainable HRM. Results of the study shows that sustainable HRM has major role to increase operational accuracy. Sustainable HRM practices has positive effect on supply chain, profitability and resource utilization. Moreover, operational accuracy has positive role to enhance supply chain, profitability and resource utilization among the cement manufacturing companies. As sustainable HRM shows positive role in operational accuracy and operational accuracy shows positive role to enhance supply chain, profitability and resource utilization. Sustainable HRM has positive effect on supply chain, profitability and resource utilization. It is found that sustainable HRM has positive effect on operational accuracy. Increase in sustainable HRM increases the operational accuracy. Therefore, it is found that increase in the operational accuracy increases the supply chain 
activities. Moreover, increase in operational accuracy increases the profitability of cement manufacturing companies. Finally, operational accuracy has the ability to increase the resource utilization.

\subsection{Implications of the Study}

The relationship between sustainable HRM, operational accuracy, supply chain, profitability and resource utilization which is examined in this study has several implications for the literature. As this relationship is first examined in the cement industry. Therefore, it has influenced the cement industry literature. Particularly, the literature on Indonesian cement industry was missing to examine this relationship. The effect of sustainable HRM in relation to the supply chain, profitability and resource utilization is first time examined in this study. Therefore, this study has several implications for the theory. The major contribution of this study belongs to the mediating role of operational accuracy. The mediating role of operational accuracy was examined between sustainable HRM and supply chain. The mediating role of operational accuracy was examined between sustainable HRM and profitability. Finally, the mediating role of operational accuracy was examined between sustainable HRM and resource utilization. Moreover, the relationship between sustainable HRM, operational accuracy, supply chain, profitability and resource utilization have several practical implications. According to the findings, Indonesian cement companies should enhance the supply chain, profitability and resource utilization to improve sustainable HRM practices. Cement companies should enhance operational accuracy to promote supply chain, profitability and resource utilization.

\subsection{Limitations and Future Directions}

After examining the comprehensive relationship between sustainable HRM, operational accuracy, supply chain, profitability and resource utilization, this study found few limitations which could be the future directions. First, the study examined the sustainable HRM effect on supply chain, profitability and resource utilization, however, there are various other factors such as competitive environment and market conditions which may affect supply chain, profitability and resource utilization of cement companies. Hence, future studies should include various external factors. Second, this study examined the mediation effect of operational accuracy and data were collected from employees of the cement industry. Various questions included in the survey were expecting biased responses, therefore, interviews are better than questionnaires in the current study. Hence, future study should include interviews in the current study.

\section{References}

Addison, P., McRae, L., Reuter, K., Starkey, M., Milner-Gulland, E., Stephenson, P., . . . Burgass, M. (2020). Bringing sustainability to life: A framework to guide biodiversity indicator development for business performance management. Business Strategy and the Environment.

Ahmad, A., Kura, K. M., Bibi, P., Khalid, N., \& rahman Jaaffar, A. (2019). Effect of Compensation, Training and Development and Manager Support on Employee Commitment: The moderating effect of Co-worker Support. Journal on Innovation and Sustainability, 10(2), 39-55.

Ahmed, W., Ashraf, M. S., Khan, S. A., Kusi-Sarpong, S., Arhin, F. K., Kusi-Sarpong, H., \& Najmi, A. (2020). Analyzing the impact of environmental collaboration among supply chain stakeholders on a firm's sustainable performance. Operations Management Research, 1-18.

Altaf, M., Hameed, W., Nadeem, S., \& Arfan, S. (2019). Successful Entrepreneurial Process as Contributor towards Business Performance in Banking: Moderating Role of Passion for Inventing. South Asian Journal of Management Sciences, 13(1).

Aydin, D., \& ŞENOĞLU, B. (2018). ESTIMATING THE MISSING VALUE IN ONE-WAY ANOVA UNDER LONGTAILED SYMMETRIC ERROR DISTRIBUTIONS. Sigma: Journal of Engineering \& Natural Sciences/Mühendislik ve Fen Bilimleri Dergisi, 36(2).

Chin, W. W. (1998). The partial least squares approach to structural equation modeling. Modern methods for business research, 295(2), 295-336.

Clavier, K. A., Watts, B., Liu, Y., Ferraro, C. C., \& Townsend, T. G. (2019). Risk and performance assessment of cement made using municipal solid waste incinerator bottom ash as a cement kiln feed. Resources, Conservation and Recycling, $146,270-279$

Darina, P., Azam, A. N., \& Bayu, B. (2020). ANALYSIS CAUSALITY OF CAPITAL STRUCTURE AND PROFITABILITY OF BANKING SECTOR LISTED IN INDONESIAN STOCKS EXCHANGE: BUKU 1, BUKU 2, BUKU 3, AND BUKU 4 OF 2014-2018 PERIOD. Russian Journal of Agricultural and Socio-Economic Sciences, 97(1).

Deng, J., Zhang, N., Ahmad, F., \& Draz, M. U. (2019). Local government competition, environmental regulation intensity and regional innovation performance: An empirical investigation of Chinese provinces. International Journal of Environmental Research and Public Health, 16(12), 2130.

F. Hair Jr, J., Sarstedt, M., Hopkins, L., \& G. Kuppelwieser, V. (2014). Partial least squares structural equation modeling (PLS-SEM) An emerging tool in business research. European Business Review, 26(2), 106-121. doi:https://doi.org/10.1016/j.jfbs.2014.01.002

Fornell, C., \& Larcker, D. F. (1981). Evaluating structural equation models with unobservable variables and measurement error. Journal of Marketing Research, 39-50. 
Giannakis, D., Chalikias, I., \& Tsirigoti, E. (2019). The Effect of Sales and HRM Strategic Alignment on a Corporate Sustainable Competitive Advantage: The Significant Role of the HR Business Partner. International Journal of Innovation, Management and Technology, 10(6).

Gonçalves, T., Silva, R., de Brito, J., Fernández, J., \& Esquinas, A. (2020). Mechanical and durability performance of mortars with fine recycled concrete aggregates and reactive magnesium oxide as partial cement replacement. Cement and Concrete Composites, 105, 103420.

Guerci, M., Decramer, A., Van Waeyenberg, T., \& Aust, I. (2019). Moving beyond the link between HRM and economic performance: A study on the individual reactions of HR managers and professionals to sustainable HRM. Journal of business ethics, 160(3), 783-800.

Hair, J. F. (2010). Black, WC, Babin, BJ, \& Anderson, RE (2010). Multivariate data analysis, 7.

Hair, J. F., Sarstedt, M., Pieper, T. M., \& Ringle, C. M. (2012). The use of partial least squares structural equation modeling in strategic management research: a review of past practices and recommendations for future applications. Long range planning, 45(5-6), 320-340. doi:https://doi.org/10.1016/j.lrp.2012.09.008

Hair Jr, J. F., Hult, G. T. M., Ringle, C., \& Sarstedt, M. (2016). A primer on partial least squares structural equation modeling (PLS-SEM): Sage Publications.

Hameed, W., \& Naveed, F. (2019). Coopetition-Based Open-Innovation and Innovation Performance: Role of Trust and Dependency Evidence from Malaysian High-Tech SMEs. Pakistan Journal of Commerce and Social Sciences, 13(1), 209-230.

Hameed, W. U., Basheer, M. F., Iqbal, J., Anwar, A., \& Ahmad, H. K. (2018). Determinants of Firm's open innovation performance and the role of R \& D department: an empirical evidence from Malaysian SME's. Journal of Global Entrepreneurship Research, 8(1), 29. doi:https://doi.org/10.1186/s40497-018-0112-8

Henseler, J., \& Chin, W. W. (2010). A comparison of approaches for the analysis of interaction effects between latent variables using partial least squares path modeling. Structural Equation Modeling, 17(1), 82-109. doi:https://doi.org/10.1080/10705510903439003

Henseler, J., Dijkstra, T. K., Sarstedt, M., Ringle, C. M., Diamantopoulos, A., Straub, D. W., . . Calantone, R. J. (2014). Common beliefs and reality about PLS: Comments on Rönkkö and Evermann (2013). Organizational Research Methods, 17(2), 182-209. doi:https://doi.org/10.1177/1094428114526928

Henseler, J., \& Fassott, G. (2010). Testing moderating effects in PLS path models: An illustration of available procedures Handbook of partial least squares (pp. 713-735): Springer.

Henseler, J., Ringle, C. M., \& Sinkovics, R. R. (2009). The use of partial least squares path modeling in international marketing New challenges to international marketing (pp. 277-319): Emerald Group Publishing Limited.

Kerdpitak, C. \& Jermsittiparsert, K. (2020). The Influence of Organizational Culture, Employee Commitment and Organization Citizen Behaviour on the HRM Practices: Mediating Role of Perceived Organization Support. Systematic Reviews in Pharmacy, 11(1), 407-415.

Khaksar, E., Abbasnejad, T., Esmaeili, A., \& Tamošaitienė, J. (2016). The effect of green supply chain management practices on environmental performance and competitive advantage: a case study of the cement industry. Technological and Economic Development of Economy, 22(2), 293-308.

Maina, W. S., \& Bula, H. (2019). Employee Training and Performance of Agency Banking Units of Selected Commercial Banks in Nairobi City County, Kenya. International Journal of Academic Research in Accounting, Finance and Management Sciences, 9(3), 240-250.

Murty, A., \& Chowdary, E. R. (2018). Effective of Interest Rates Changes on Profitability of Banking Industry in India (An Empirical Research on the Profitability Performance of Nationalized Banks in India). IOSR Journal of Business and Management (IOSR-JBM), 20 (2), 82, 91.

Omrani, S., Jafari, M., \& Mansori, A. (2019). Analysis of Financial Performance of Cement Industry Manufacturing Companies in Tehran Stock Exchange Using the FAHP Technique and the TOPSIS Method. Independent Journal of Management \& Production, 10(2), 512-536.

Pöchmüller, M., Schwingshackl, L., Colombani, P. C., \& Hoffmann, G. (2016). A systematic review and meta-analysis of carbohydrate benefits associated with randomized controlled competition-based performance trials. Journal of the international society of sports nutrition, 13(1), 27.

Preacher, K. J., \& Hayes, A. F. (2008). Asymptotic and resampling strategies for assessing and comparing indirect effects in multiple mediator models. Behavior research methods, 40(3), 879-891.

Rajan, S., Amaranathan, A., Lakshminarayanan, S., Sureshkumar, S., Joseph, M., \& Ramakrishnaiah, V. P. N. (2019). Appropriateness of American Society for Gastrointestinal Endoscopy Guidelines for Upper Gastrointestinal Endoscopy: A Prospective Analytical Study. Cureus, 11(2).

Saleh, H. M., El-Sheikh, S. M., Elshereafy, E. E., \& Essa, A. K. (2019). Performance of cement-slag-titanate nanofibers composite immobilized radioactive waste solution through frost and flooding events. Construction and Building Materials, 223, 221-232.

Sarc, R., Seidler, I., Kandlbauer, L., Lorber, K., \& Pomberger, R. (2019). Design, quality and quality assurance of solid recovered fuels for the substitution of fossil feedstock in the cement industry-Update 2019. Waste Management \& Research, 37(9), 885-897.

Sharma, A., \& Khanna, P. (2020). Relevance of Adopting Emerging Technologies in Outbound Supply Chain: New Paradigm for Cement Industry. Operations and Supply Chain Management: An International Journal, 13(2), 210-221. 
Shubbar, A. A., Al-Shaer, A., AlKizwini, R. S., Hashim, K., Al Hawesah, H., \& Sadique, M. (2019). Investigating the influence of cement replacement by high volume of GGBS and PFA on the mechanical performance of cement mortar. Paper presented at the IOP Conference Series: Materials Science and Engineering.

Siuly, Li, Y., \& Wen, P. (2011). EEG signal classification based on simple random sampling technique with least square support vector machine. International journal of Biomedical Engineering and Technology, 7(4), 390-409.

Snapp, S. S., Grabowski, P., Chikowo, R., Smith, A., Anders, E., Sirrine, D., . . . Bekunda, M. (2018). Maize yield and profitability tradeoffs with social, human and environmental performance: Is sustainable intensification feasible? Agricultural systems, 162, 77-88.

Ul-Hameed, W., Mohammad, H., Shahar, H., Aljumah, A., \& Azizan, S. (2019). The effect of integration between audit and leadership on supply chain performance: Evidence from UK based supply chain companies. Uncertain Supply Chain Management, 7(2), 311-328. doi:https://doi.org/10.5267/j.uscm.2018.8.001

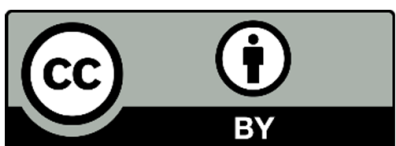

(C) 2022 by the authors; licensee Growing Science, Canada. This is an open access article distributed under the terms and conditions of the Creative Commons Attribution (CC-BY) license (http://creativecommons.org/licenses/by/4.0/). 